\title{
The role of scout activities and learning environment at school toward students' characters
}

\author{
Nelly Astuti ${ }^{1^{*}}$ \\ Fadhilah Khairani \\ Frida Destini ${ }^{3}$ \\ Sulistyawati ${ }^{4}$ \\ ${ }^{1-4}$ Faculty of Teacher Training and Education, Universitas Lampung, Bandar Lampung, Indonesia
}

\begin{abstract}
This study aimed to determine the role of scout extracurricular activities toward student characters, between the learning environment at school and the student characters, and between scout extracurricular activities and the learning environment at school along with students' characters. The research adopted an ex-post-facto correlation with a total population of 112 students and 54 of them were taken as samples. Observation and questionnaires were used for data collection. Product Moment Correlation and Multiple Correlation were undertaken to analyze the collected data. Based on the analysis, the results of the study indicated that there was a relationship between scout extracurricular activities and learning environment at school toward students' characters.
\end{abstract}

\section{KEYWORDS}

Scout extracurricular activities; learning environment; student's character

Received: 31 January 2021 Accepted: 2 February 2021 Published: 4 February 2021

\section{Introduction}

Education is one of the components that has an important role for a country. With education, all citizens can develop all of their potential and increase their insight, knowledge and talents. It is one of activities that is useful for enriching intellectual life of the nation, because it is able to form the character of a nation. If education in a country is developed, automatically, the country will become a developed country because basically education is the foundation for the progress of a nation. Education develops a country's economy and society; therefore, it is the milestone of a nation's development. Education provides knowledge and skills to the population, as well as shaping the personality of the youth of a nation (Idris, Hassan, Ya'acob, Gill, \& Awal, 2012).

Education is a process of behavior change that occurs in students which are manifested in their personality. The formation of student's personality is determined by the environment wherever they are, school or community. Change is not only related to the enrichment of knowledge, but also in the form of abilities, skills, attitudes, self-esteem, interests, character, and selfadjustment. Education should be a means to empower children and adults alike to become active 
participants in the transformation of their societies. Learning should also focus on the values, attitudes and behaviors which enable individuals to learn and to live together in a world characterized by diversity and pluralism (Idris et al., 2012).

Education should not only focus on intellectual or cognitive development, but also on soft skills or non-academic aspects as an element of education character, those aspects must also be considered. Character building and strengthening are a must in the educational process. Education should not be oriented only on cognitive development, but also affective development such as attitude, and politeness, thus they are expected to be more sociable. It is suggested that childhood phase is the most optimal phase to build characters. It is reported that student's behavior has shown poor characters, such as lying to their parents and teachers, plagiarizing friends' assignments, and not obeying school rules. Therefore, it is necessary to build characters from an early age (Afifah et al., 2020).

The word 'character' comes from Greek which means "to mark" and focuses on how to apply the values of kindness in real actions or everyday life (Kamali, 2016). It is stated that there are 18 values that must be developed in determining the success of character education (Fitri, 2012). Values that must be developed in character education are: religious, honest, tolerance, discipline, hard work, creative, independent, democratic, curiosity, national spirit, love for the country, respect for achievement, friendly/communicative, peace-loving, fond of reading, care for the environment, care for social, and responsibility.

Characters do not just form, but there are factors that influence them, they are biological and environmental factors. According to Agustiana (2015), biological factor is the aspect that comes from a person and environmental factor consists of life environment, education, situations and conditions of society. The environment is everything around humans that can affect behavior directly or indirectly. The environment affects student activities and character development, and personality.

The learning environment in schools includes two main things, they are the physical environment and the social environment. The physical environment is the environment around students both in class and at school. The physical environment includes classroom conditions, facilities that support learning, and learning media in schools. The social environment is related to the patterns of interaction between personnel in the school environment in general. The social environment (non-physical) includes student interactions between teachers, between students, and between students and school employees. Schellens (as cited in Kintu \& Zhu, 2016)) states that learning environment is very important for stimulating and supporting student learning. The learning environment in schools affects the students' character development. A good school learning's environment will have a good influence on the development of children's character.

Besides being influenced by the learning environment at school, the character values of students can also be influenced through various extracurricular activities. Extracurricular activities are activities that are carried out outside of the class and in class hours to develop students' potential (Al Azizi, 2020). Fletcher et al. (2003) state that children who are heavily involved in a variety types of extracurricular will show more positive adjustment than their less involved peers. Extracurricular activities can be implemented to grow and to develop the students' character. Extracurricular activities aim to broaden knowledge and recognize relationships between various subjects, extend interests, talents, and complete topics in the context of fostering whole human beings (Erlamsyah \& Daharnis (as cited in (Ramadhani \& Suharini, 2021). Furthermore, according to Masrukhi (as cited in Ramadhani \& Suharini, 2021), what needs to be underlined is that extracurricular activities have the spirit to occur either in development process, social process, or creative process. The development process means that extracurricular activities are intended to develop students' potential through interaction with their environment.

One of the extracurricular activities at school is scouting (Indonesian: Pramuka). It is an acronym for Praja Muda Karana which means a creative society. Scouting activities or Scout is nonformal education which is conducted through coaching and practical development outside the school (formal) and family (informal) environment which is carried out in the nature (wild) in the form of activities that are interesting, challenging, fun, healthy, organized, and directed based on 
the basic principles and methods of scouting (Firmansyah, 2014). Scout is good for human's character building which is proven to be able to create independent and responsible people (Hudiyono, 2012). Therefore, scout activity is one of activities outside of class hours which is appropriate to instill character values to students. Character education in schools through scouting activities can be implemented properly if it is supported by the involvement of the concerned parties (Mislia et al., 2016).

Observations were conducted at elementary schools in RA Kartini area, Lampung Province, Sumatra island, Indonesia. We distributed a questionnaire to teachers in the schools to find out character values of the fifth-grade students. We limited our scope to only three characters to be studied, they were discipline, responsibility and honesty. Student character is optimal if that character is done by more than $80 \%$ of students. The following are data of the character values of the fifth-grade students taken from the public elementary schools.

Table 1. Character values of the fifth-grade students of elementary school in RA Kartini area

\begin{tabular}{lccccccc}
\hline & \multirow{2}{*}{$\begin{array}{c}\text { Number } \\
\text { School's name }\end{array}$} & $\begin{array}{c}\text { of } \\
\text { students }\end{array}$ & \multicolumn{2}{c}{ Discipline } & \multicolumn{2}{c}{ Responsible } & \multicolumn{2}{c}{ Honesty } \\
\cline { 3 - 8 } & & Optimal & $\begin{array}{c}\text { Not } \\
\text { optimal }\end{array}$ & Optimal & $\begin{array}{c}\text { Not } \\
\text { optimal }\end{array}$ & Optimal & $\begin{array}{c}\text { Not } \\
\text { optimal }\end{array}$ \\
\cline { 3 - 8 } & & Percentage & Percentage & Percentage \\
\hline SD Negeri 1 Untoro & 25 & $88 \%$ & $12 \%$ & $75 \%$ & $25 \%$ & $80 \%$ & $20 \%$ \\
\hline SD Negeri 2 Untoro & 15 & $87 \%$ & $13 \%$ & $80 \%$ & $20 \%$ & $80 \%$ & $20 \%$ \\
\hline $\begin{array}{l}\text { SD Negeri 1 } \\
\text { Notoharjo }\end{array}$ & 14 & $86 \%$ & $14 \%$ & $71 \%$ & $29 \%$ & $71 \%$ & $29 \%$ \\
\hline $\begin{array}{l}\text { SD Negeri 2 } \\
\text { Notoharjo }\end{array}$ & 16 & $81 \%$ & $19 \%$ & $56 \%$ & $44 \%$ & $63 \%$ & $37 \%$ \\
\hline $\begin{array}{l}\text { SD Negeri 3 } \\
\text { Notoharjo }\end{array}$ & 21 & $86 \%$ & $14 \%$ & $81 \%$ & $19 \%$ & $71 \%$ & $29 \%$ \\
\hline $\begin{array}{l}\text { SD Negeri 1 Purwo } \\
\text { Adi }\end{array}$ & 21 & $90 \%$ & $10 \%$ & $71 \%$ & $29 \%$ & $76 \%$ & $24 \%$ \\
\hline Average & & $86 \%$ & $14 \%$ & $72 \%$ & $28 \%$ & $74 \%$ & $27 \%$ \\
\hline
\end{tabular}

Based on Table 1, it can be seen that the character of student discipline has been optimal with an average percentage of $86 \%$, but the average of character responsibility and honesty is still not optimal. Students' characters that were not optimal are due to external factors such as the learning environment at school and students' activity in organizations. From the observation seen that the teachers who do not take advantage of the learning environment at school and do not provide characters' education to the students. Based on these conditions, scout extracurricular activities and a good school's learning environment are expected to attract students' attention so that the students will have the expected characters.

Therefore, this study was aimed at: (1) finding out the relationship between scout extracurricular activities and students' character; (2) investigating the relationship between the learning environment at school and students' character; (3) finding out the relationship between scout extracurricular activities and learning environment in schools along with the characters of the fifth-grade students of public elementary schools in RA Kartini area, Lampung Province on Sumatra island, Indonesia.

\section{Literature review}

Education should not be oriented only on cognitive development, but also on effective development such as attitude, and politeness, thus they are expected to be more sociable. It is suggested that the childhood phase is the most optimal to build character. The character comes from Greek which means "to mark" and focuses on how to apply the values of kindness in real actions or everyday life (Kamali, 2016). It is stated that there are 18 values that must be developed in determining the success of character education (Fitri, 2012). Values that must be developed in 
character education are religion, honest, tolerance, discipline, hard work, creativity, independence, democratic, curiosity, national spirit, love for the country, respect for achievement, friendly/communicative, peace-loving, fond of reading, care for the environment, care for social, and responsibility.

A character can be influenced by both biological and environmental factors. Biological factors, according to Agustiana (2015), are aspects that come from a person and environmental factors include environment, education, situations, and conditions of society. Environment refers to everything around humans that can influence behavior either directly or indirectly. The environment affects student activity and the development of student character. Kintu \& Zhu (2016) stated that the learning environment is very important to stimulate and support student learning. The learning environment at school affects the character development of students. A good school learning environment will have a good effect on children's character development. Apart from being influenced by the learning environment at school, students' character values can also be influenced through extracurricular activities. Extracurricular activities are activities that are carried out outside of the class and in-class hours to develop the student's potential (Al Azizi, 2020). One of the extracurricular activities at school is scouting.

Pramuka (Scout) is an acronym for Praja Muda Karana which means a creative society. Scouting activities are non-formal education which is conducted through coaching and practical development outside the school (formal) and family (informal) environment which is carried out in nature (wild) in form of activities that are interesting, challenging, fun, healthy, organized, and directed based on the basic principles and methods of scouting (Firmansyah, 2014). Scouting skills are material about scouting obtained by a scout member from the attended activities. These skills become the provision of practical knowledge that is ready to be used at any time. Scouting skills are a must for students. Society assumes that every member of scout certainly has knowledge and skills that can be used as a basis to solve problems in daily life (Mislia et al., 2016).

Based on this, scouting activities and student learning environments need to be considered so that they can shape characters to be even better. Scout activities referred to in this research include (1) scouting ceremony; (2) training marching; (3) rigging training; (4) training on code usage. The learning environment in the school referred to in this study is a place of learning, learning tools, learning atmosphere, study time, student associations, while the characters referred to in this study are discipline, responsibility, and honesty.

\section{Methods}

\section{Participant}

This type of research is ex-post-facto correlation. This is done w to find out the strength or weakness of a relationship between two or more variables, which is to determine the level of relationship between scout extracurricular activities and learning environment in schools towards the characters of the fifth-grade students of SD Negeri in RA Kartini area, Lampung Province. The research was conducted from November to May 2018. The research was carried out at public elementary schools in RA Kartini with a total population of 112 the fifth-grade students of public elementary schools. The sample was determined by using a probability sampling technique, 54 students were taken as samples.

The stages of the post-facto correlation research were conducted as follows: (1) selecting research subjects; (2) preparing grids and data collection instruments; (3) testing the instrument on the test's subject of the questionnaire instrument; (4) analyzing data from the tests' results of the instrument to determine the validity and reliability; (5) conducting research by using a questionnaire instrument to the research's sample; (6) analyzing the data obtained to determine the relationship and level of relationship between scout extracurricular activities and the learning environment toward students' character; and (7) interpretating the results of the data analysis.

The data were collected through observation, questionnaire, and documentation. Observations in this study were carried out to obtain data about school conditions or a description 
of the location of the research which was carried out in public elementary schools in RA Kartini area, Lampung Province. The data collection tool was in the form of a closed questionnaire by using a Likert scale without a choice of neutral answers to obtain data about scout extracurricular activities, school learning environment and students' character.

\section{Instrument}

The research instruments were in the forms of students' character questionnaires, scout activities and learning environment in schools. The students' characters grid (Y) were as follows: (1) discipline; (2) responsibility; (3) honesty. The grid for scout activities $\left(\mathrm{X}_{1}\right)$ were as follows: (1) scout ceremony; (2) marching training; (3) rigging training; (4) training on the use of codes; the learning environment grid at school $\left(\mathrm{X}_{2}\right)$ was as follows: (1) place of study; (2) learning tools; (3) learning atmosphere; (4) study time; (5) student association. The purpose of testing the instrument was to determine the validity and reliability of the questionnaire so that the students' character questionnaire, scout extracurricular activities and learning environment in schools were suitable for the research and able to collect data in accordance with what was studied. To test the validity of the instrument the Pearson Product Moment Correlation formula was used, while Alpha Cronbach technique was used to test the reliability.

\section{Data analysis}

The collected data were analyzed through quantitative approach. The prerequisite test for data analysis was a normality test with the chi squared formula and a linearity test using F-test. Pearson Product Moment and Multiple Correlation formula and the F-test were used to test the hypotheses, while determining the contribution of the $X_{1}$ variable (scout extracurricular activities), the $\mathrm{X}_{2}$ (school learning environment) and $\mathrm{Y}$ (students' character) variables was tested with the determinant coefficient formula.

\section{Results}

\section{Description of research data}

Based on the results of research and documentation carried out among the fifth-grade students of public elementary schools located in RA Kartini area, Lampung Province on 28, 30, and 31 May 2018, the data obtained were as follows. The following is a description of the frequency of the Y variable data (students' character).

Table 2. Character distribution (Y)

\begin{tabular}{cccc}
\hline No. & Interval & Frequency & Percentage (\%) \\
\hline $\mathbf{1}$ & $33-35$ & 3 & 5,56 \\
\hline $\mathbf{2}$ & $36-38$ & 3 & 5,56 \\
\hline $\mathbf{3}$ & $39-41$ & 14 & 25,93 \\
\hline $\mathbf{4}$ & $42-44$ & 10 & 18,52 \\
\hline $\mathbf{5}$ & $45-47$ & 13 & 24,07 \\
\hline $\mathbf{6}$ & $48-50$ & 5 & 9,26 \\
\hline $\mathbf{7}$ & $51-53$ & 6 & 11,11 \\
\hline & total & 54 & \\
\hline
\end{tabular}

Table 2 shows that the highest frequency is found in the interval class $39-41$ which is 14 participants, while the lowest is in the interval class 33-35 and 36-38 with a total of three participants. Based on the Table 2 above, it is clear that $5.56 \%$ of students' characters are in the very low category. This indicates that the characters of students still need attention. More details can be seen in the following histogram. 


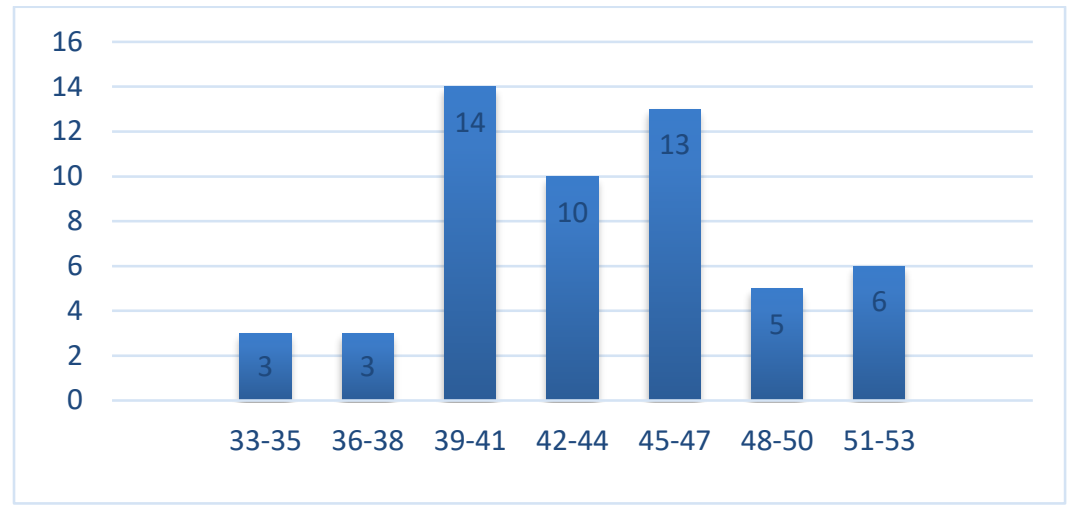

Figure 1. The histogram of the $\mathrm{Y}$ frequency distribution

The variable frequency distribution $\mathrm{X}_{1}$ can be seen in the following Table 3 .

Table 3. The distribution of the variable frequency $\mathrm{X}_{1}$ (scout extracurricular activities)

\begin{tabular}{cccc}
\hline No. & Interval & Frequency & Percentage (\%) \\
\hline $\mathbf{1}$ & $36-38$ & 2 & 3,70 \\
\hline $\mathbf{2}$ & $39-41$ & 7 & 12,96 \\
\hline 3 & $42-44$ & 15 & 27,78 \\
\hline $\mathbf{4}$ & $45-47$ & 11 & 20,37 \\
\hline $\mathbf{5}$ & $48-50$ & 6 & 11,11 \\
\hline $\mathbf{6}$ & $51-53$ & 10 & 18,52 \\
\hline $\mathbf{7}$ & $54-56$ & 3 & 5,56 \\
\hline & total & 54 & \\
\hline
\end{tabular}

Table 3 shows that the highest frequency is in the interval class 42-44, that is 15 students, while the lowest is in the 36-38 interval class of 2 students. Based on the Table 3 above, it is apparent that $3.7 \%$ of scout as the extracurricular activities are in the very low category. This shows that scout extracurricular activities still need to be improved. More details can be seen in the following histogram.

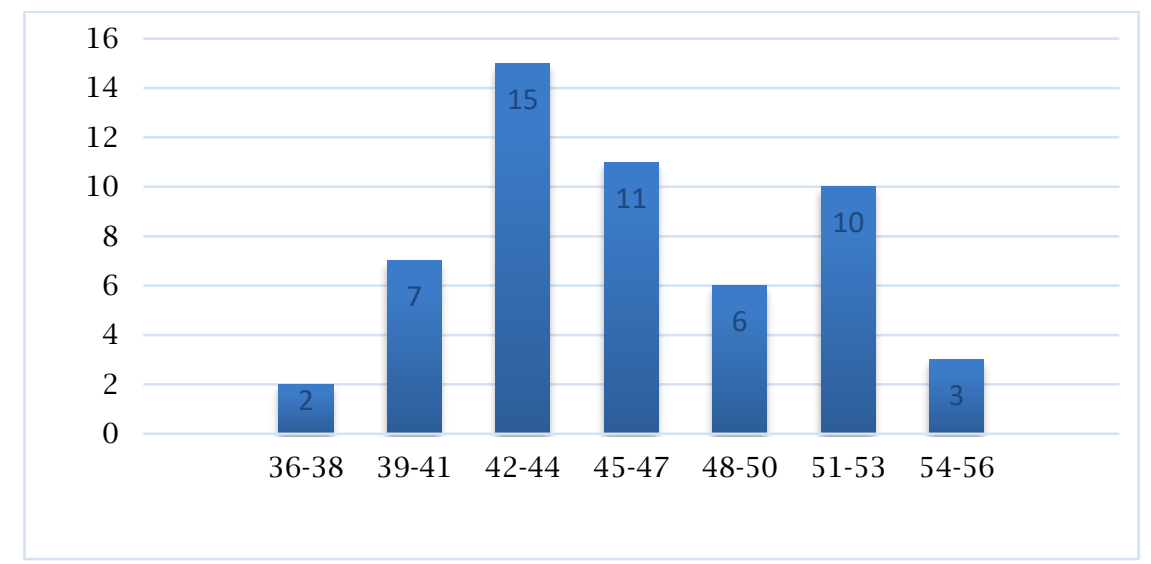

Figure 2. The histogram of the $\mathrm{X}_{1}$ frequency distribution

The distribution of the variable frequency $\mathrm{X}_{2}$ can be seen in the following Table 4 . 
Table 4. The distribution of the variable frequency $\mathrm{X}_{2}$ (learning environment at school)

\begin{tabular}{cccc}
\hline No. & Interval & Frequency & Percentage (\%) \\
\hline $\mathbf{1}$ & $28-31$ & 2 & 3,70 \\
\hline $\mathbf{2}$ & $32-35$ & 5 & 9,26 \\
\hline $\mathbf{3}$ & $36-39$ & 6 & 11,11 \\
\hline $\mathbf{4}$ & $40-43$ & 11 & 20,37 \\
\hline $\mathbf{5}$ & $44-47$ & 14 & 25,93 \\
\hline $\mathbf{6}$ & $48-51$ & 9 & 16,67 \\
\hline $\mathbf{7}$ & $52-55$ & 7 & 12,96 \\
\hline & Total & 54 & \\
\hline
\end{tabular}

Table 4 shows that the highest frequency is in the interval class 44-47, that is 14 people, while the lowest is in the 28-31 interval class with a total of 2 people. Based on the Table 4 above, it is known that $3.7 \%$ of the learning environment in schools is in the very low category. This shows that the learning environment in schools still needs to be improved. More details can be seen in the following histogram.

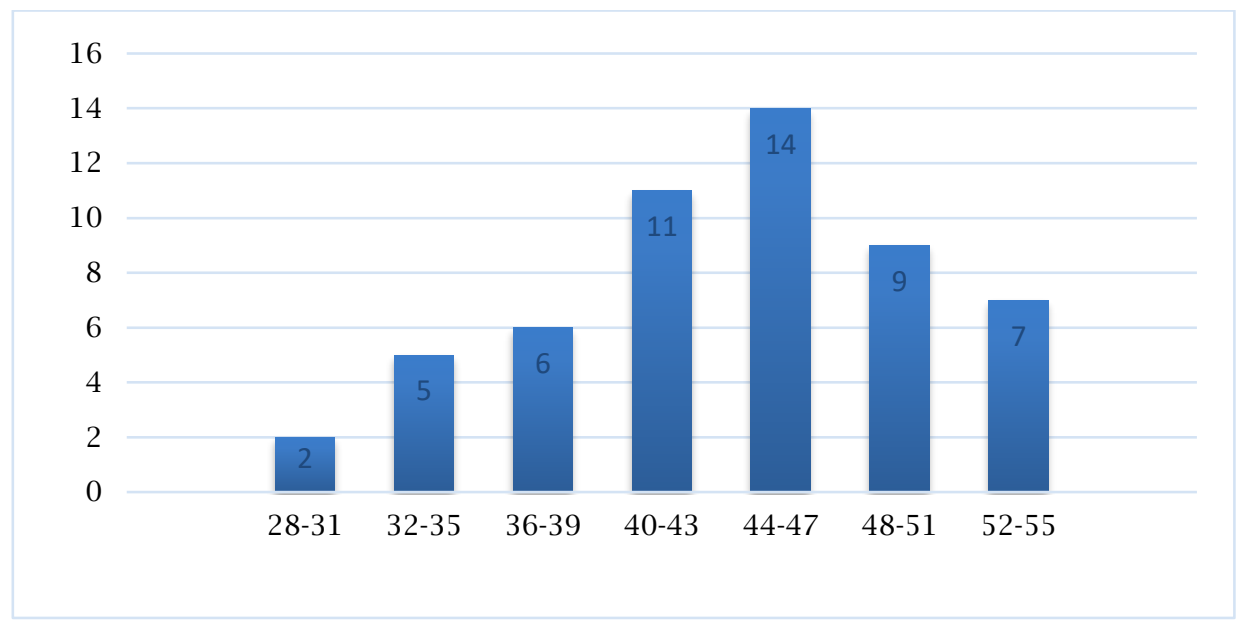

Figure 3. The histogram of the $\mathrm{X}_{2}$ frequency distribution

\section{Pretest Data Analysis}

There were three data that were needed to be tested for normality, they were on variable $X_{1}$ (scout as extracurricular activities), variable $\mathrm{X}_{2}$ (learning environment at school) and variable $\mathrm{Y}$ (character of the fifth-grade students in public elementary schools located in RA Kartini area). The interpretation of the calculation results was carried out by comparing the $\mathrm{X}_{\text {2count }}$ with the $\mathrm{X}_{\text {2table }}$ for $\alpha$ $=0.05$ with $\mathrm{dk}=\mathrm{k}-1$ with the help of Microsoft Office Excel 2010.

The results of the normality test for the $X_{1}$ variable was that $X_{\text {2count }}=6.704<X_{\text {table }}=12.592$, which means that the data for the $X_{1}$ variable were normally distributed. Furthermore, the normality test on the $\mathrm{X}_{2}$ variable was that $\mathrm{X}_{2 \text { count }}=3.271<\mathrm{X}_{\text {2table }}=12.592$ that means that the data for $\mathrm{X} 2$ variables were also normally distributed. The normality test on variable $\mathrm{Y}$ was that $\mathrm{X}_{\text {2count }}=7.221<$ $\mathrm{X}_{\text {2table }}=12.592$.

Based on the normality test above, it was found out that the data for variables $X_{1}, X_{2}$, and variable $\mathrm{Y}$ were normally distributed, then the linearity test was then carried out with the help of Microsoft Office Excel 2010. Based on the linearity test of variable $\mathrm{X}_{1}$ and variable $\mathrm{Y}$, it was found that $\mathrm{F}_{\text {count }}=1.63<\mathrm{F}_{\text {table }}=1.96$ which means that the data were linearly patterned. The results of the 
normality test of the variables $\mathrm{X}_{2}$ and the variable $\mathrm{Y}$ showed that $\mathrm{F}_{\text {count }}=1.06<\mathrm{F}_{\text {table }}=1.91$, which means the data had a linear pattern.

\section{Hypothesis Testing}

Based on the results of the first hypothesis testing in this study, the correlation coefficient between $\mathrm{X}_{1}$ and $\mathrm{Y}$ variable is 0.642 which is positive with moderate criteria. The correlation coefficient between $X_{2}$ and variable $Y$ is 0.090 which is positive with very low criteria. The correlation coefficient between $X_{1}$ and $X_{2}$ along with the $Y$ variable is 0.652 which is positive with low criteria. Furthermore, the contribution of variables $X_{1}$ and $X_{2}$ to variable $Y$ was $42.51 \%$. This means that scout as extracurricular activities and learning environment in schools have an effect of $42.51 \%$ on the characters of the fifth-grade students of public elementary schools located in RA Kartini area, Lampung Province. The remaining 57.49\% were influenced by other factors.

The significance value of $\mathrm{F}_{\text {count }}=19.27>\mathrm{F}_{\text {table }}=3.18$ which means significant. This means that the hypothesis is accepted, there is a significant relationship between scout extracurricular activities and learning environment at schools along with characters of the fifth-grade students of public elementary schools in RA Kartini area, Lampung Province.

\section{Discussion}

Based on the results of the hypothesis testing above, the correlation coefficient between variable $\mathrm{X}_{1}$ and variable $\mathrm{Y}$ is 0.642 , which means that the correlation is positive with moderate criteria. Furthermore, we know that the contribution of variable $\mathrm{X}_{1}$ to variable $\mathrm{Y}$ is $41.22 \%$. This means that scout as the extracurricular activities have an effect of $41.22 \%$ on students' characters. This means that from the overall description above, it is found out that there is a significant relationship between scout extracurricular activities on the fifth-grade students' character. Based on the results of hypothesis testing, this study is in line with several studies conducted by (Anggraini, 2017; Maulidina et al., 2019; Ramadhani \& Suharini, 2021; Ulomo, 2015). Based on the results of the study, it was concluded that there was a relationship between scout extracurricular activities and the students' character.

Aqib and Sujak (as cited in Rosyadi, 2012) stated that scouting is an educational process outside of school and outside the family environment in the form of interesting, fun, regular, directed, and practical activities that are carried out in nature. Scout extracurricular activities will connect the talents, interests and creativity of students. Scouting extracurricular activities using the basic principles of scouting and the among system are considered as capable to form the characters of students.

A good character is influenced by many factors, one is gained from scout extracurricular activities. The implementation of good scout extracurricular activities will certainly have an impact on the character of students. This is in accordance with the proposed hypothesis, that there is a significant relationship between scout extracurricular activities on the characters of the fifth-grade students of public elementary schools located in RA Kartini area, Lampung Province.

It is also found that the correlation coefficient between variable $\mathrm{X}_{2}$ and variable $\mathrm{Y}$ is 0.090 , which means that the correlation is positive with very low criteria. Furthermore, we know that the contribution of variable $\mathrm{X}_{2}$ to variable $\mathrm{Y}$ is $0.81 \%$. This means that the learning environment in the school has an influence of $0.81 \%$ on the characters of the fifth-grade students. This means that from the overall description above, it is known that there is a significant relationship between learning environment at school and students' character. Based on the results of hypothesis testing, this study resonates with several other studies conducted by Kamaruddin (2012) and Pratiwi et al., (2018). Based on the research results, it can be concluded that there is a significant relationship between school environment and characters of students.

Schools have a very important role in children's character education, especially if the children do not get character education at home. According to Hamalik (as cited in Rustiana \& Chalifah, 2012) learning environment at school is a condition that exists in school which has a certain meaning and influence on the students. The learning environment in schools is one of 
important components in an effort to create superior character in students. The better the conditions of the learning environment at school, the better the character they have.

The character of students is also influenced by many factors, one is learning environment at school. The learning environment in a good school has an impact on the character of students. This is in accordance with the proposed hypothesis, that there is a relationship between the learning environment at school and the character of the fifth-grade students of public elementary schools located in RA Kartini area, Lampung Province.

Based on the results of the calculation of the hypothesis test, it is found out that the correlation coefficient between variables $\mathrm{X}_{1}, \mathrm{X}_{2}$ and variable $\mathrm{Y}$ is 0.652 , which means that the correlation is positive with moderate criteria. Furthermore, it is known that the contribution of variables $X_{1}$ and $X_{2}$ to variable $Y$ is $42.51 \%$. This means that scout extracurricular activities and the learning environment in schools have an effect of $42.51 \%$ on the character of the fifth-grade students. This means that from the overall description above, it is known that there is a relationship between scout extracurricular activities and learning environment at school toward characters of students in scout extracurricular activity class and learning environment at school makes an effect of $42 \%$. Based on the results of hypothesis testing, this study is in line with several other studies, e.g., (Kamaruddin, 2012; Anggraini, 2017; Hastuti, 2008; Maulidina et al., 2019; Pratiwi et al., 2018; Ramadhani \& Suharini, 2021; Ulomo, 2015).

Based on the results of the study it can be stated that there is a relationship between scout extracurricular activities and learning environment at school toward the character of students. Scout extracurricular activities and learning environment at school are factors that can affect students' character. Students who are active in scouting extracurricular activities and always apply them in their daily life tend to have good characters. The school environment will affect student development, directly and indirectly. Attitudes and behavior of students are formed from the environment in which these students grow and interact. A good school learning environment will form a good character in students. That matter is in accordance with the proposed hypothesis, that there is a relationship between scout extracurricular activities and learning environment at school together with the character of the fifth-grade students of public elementary schools located in RA Kartini area, Lampung Province.

\section{Conclusion}

Based on the results of research and discussion, it can be concluded that there is a relationship between scout extracurricular activities on students' character; there is a relationship between learning environment at school towards character of students and; there is a relationship between scout extracurricular activities and learning environment in schools toward the characters of the fifth-grade students of public elementary schools located in RA Kartini area, Lampung Province. Therefore, the general conclusion is that scout extracurricular is able to shape the students' character such as patiently, honesty, and responsibility.

\section{Acknowledgements}

The authors express gratitude to the principals, teachers, and the fifth-grade students of public elementary schools located in RA Kartini area, Lampung Province. We would also love to show our gratitude to the anonymous referees who provided constructive suggestions on the earlier version of this paper.

\section{Funding}

This research received no specific grant from any funding agency in the public, commercial, or not-for-profit sectors. 


\section{References}

Afifah, H. M., Wira, D., \& Kusuma, Y. (2020). The substitution of physical education with sekolah alam student scout learning activities as the means of strengthening education based character building in natural elementary school Ar-Ridho Semarang. 9(8), 112-116.

Agustiana, S. L. (2015). Hubungan latar belakang keluarga terhadap pembentukan karakter siswa di MTS. UIN Sunan Ampel Surabaya.

Al Azizi, N. Q. U. (2020). Kegiatan ekstrakurikuler kepramukaan terhadap pendidikan karakter kedisiplinan. Jurnal Pendidikan Luar Sekolah, 12(2), 1. https://doi.org/10.32832/jpls.v12i2.2793

Anggraini, D. (2017). Hubungan kegiatan ektrakurikuler pramuka dengan karakter siswa kelas V SD negeri No.64/I Muara Bulian tahun 2017. Universitas Jambi.

Firmansyah, Z. A. (2014). Panduan Resmi Pramuka. Wahyumedia.

Fitri, A. Z. (2012). Pendidikan Karakter berbasis nilai dan etika di sekolah. Ar-Ruzz Media.

Fletcher, A. C., Nickerson, P., \& Wright, K. L. (2003). Structured leisure activities in middle childhood: Links to well-Being. Journal Of Community Psychologi, 31(6), 641-659. https://doi.org/10.1002/jcop.10075

Hastuti, T. A. (2008). Kontribusi ekstrakurikuler bolabasket terhadap pembimbitan atlet dan peningkatan kesegaran jasmani. Pendidikan Jasmani Indonesia, 5(1), 45-50.

Hudiyono. (2012). Membangun karakter siswa: Melalui profesionalisme guru dan gerakan pramuka. Esensi Erlangga.

Idris, F., Hassan, Z., Ya'acob, A., Gill, S. K., \& Awal, N. A. M. (2012). The role of education in shaping youth's national identity. Procedia - Social and Behavioral Sciences, 59, 443-450. https://doi.org/10.1016/j.sbspro.2012.09.299

Kamali, N. (2016). Konsep pendidikan karakter pada kisah Nabi Ibrahim AS. dalam Al Qur'an. UIN Sunan Ampel Surabaya.

Kamaruddin, S.A. (2012). Character education and students social behavior. Journal of Education and Learning (EduLearn), 6(4), 223. https://doi.org/10.11591/edulearn.v6i4.166

Kintu, M. J., \& Zhu, C. (2016). Student characteristics and learning outcomes in a blended learning environment intervention in a Ugandan University mountains of the moon university and Vrije Universiteit Brussel. The Electronic Journal of E-Learning Volume, 14(3), 181-195.

Maulidina, R., Sulistiasih, \& Astuti, N. (2019). Hubungan keaktifan dalam ekstrakurikuler pramuka dengan sikap disiplin. Jurnal Pedagogi, 1(8).

Mislia, Mahmud, A., \& Manda, D. (2016). The Implementation of character education through scout activities. International Education Studies, 9(6), 130. https://doi.org/10.5539/ies.v9n6p130

Pratiwi, N.P.E.A, Suarjana, I.M. \& Renda, N.T. (2018). Korelasi antara lingkungan belajar dan minat belajar siswa dengan hasil belajar matematika. Jurnal Ilmiah Sekolah Dasar, 2(3), 347-355.

Ramadhani, K., \& Suharini, E. (2021). The effect of scout extracurricular to the integrity of the students in elementary school. 10(3), 304-310.

Rosyadi, A. F. A. (2012). Pengaruh minat mengikuti kegiatan ekstrakurikuler kepramukaan terhadap kedisiplinan pada siswa kelas V SD se gugus II Kecamatan Pengasih Kabupaten Kulon Progo. Universitas Negeri Yogyakarta.

Rustiana, A., \& Chalifah, N. (2012). Pengaruh lingkungan belajar dan kompetensi profesional guru terhadap prestasi belajar siswa SMA N 1 Jekulo Kudus. Dinamika Pendidikan, 71$)$, 14-28. https://doi.org/10.15294/dp.v7i1.4914

Ulomo, C. (2015). Hubungan Keaktifan mengikuti kegiatan ekstrakurikuler pramuka dan perhatian orang tua dengan kemandirian belajar siswa di SD 1 Colo Kecamatan Dawe Kabupaten Kudus. Universitas Sebelas Maret Surakarta. 